\title{
Agroforestry for high value tree systems in Europe
}

A. Pantera ${ }^{1}$, P.J. Burgess ${ }^{2}$, R. Mosquera Losada ${ }^{3}$, G. Moreno ${ }^{4}$, M.L. López-Díaz ${ }^{4}$, N. Corroyer ${ }^{5}$, J. McAdam , A. Rosati ${ }^{7}$, A.M. Papadopoulos ${ }^{1}$, A. Graves ${ }^{2}$, A. Rigueiro Rodríguez ${ }^{3}$, N. Ferreiro-Domínguez ${ }^{3811}$, J.L. Fernández Lorenzo ${ }^{3}$, M.P. González-Hernández ${ }^{3}$, V.P.Papanastasis ${ }^{8}$, K.Mantzanas ${ }^{8}$, P. Van Lerberghe ${ }^{9}$ and N. Malignier ${ }^{10}$

1 Forestry and Natural Environment Management, TEI Stereas Elladas, Karpenissi,

2 Cranfield University, Cranfield, Bedfordshire, MK43 OAL, UK,

3 Department of Crop Production, EPS, University of Santiago de Compostela. University Campus, 27002-Lugo, Spain,

4 Forest Research Group (INDEHESA). University of Extremadura. Plasencia 10600, Spain,

5 Chambre d'agriculture de Normandie, Chemin de la Bretèque, CS 30059, 76232 Bois Guillaume Cedex, France,

6 Agri Food and Biosciences Institute, Newforge Lane, Belfast BT95PX, UK,

7 Consiglio per la ricerca in agricoltura e l'analisi dell'economia agraria, centro di ricerca per l'olivicoltura e l'industria olearia (CREA - OLI), via Nursina 2, 06049 Spoleto (PG), Italy,

8 Aristotle University of Thessaloniki, Department of Forestry \& Natural Environment, Thessaloniki, Greece

9 Institut pour le Développement Forestier, Auzeville-Tolosane, France

10 Association Française d'Agroforesterie, Auch, France

11 Forest Research Centre, School of Agriculture, University of Lisbon, Tapada da Ajuda s/n, 1349-017 Lisbon, Portugal

Corresponding author: A. Pantera, E-mail: pantera@teiste.gr

\begin{abstract}
Most farm-based agroforestry projects focus on the integration of trees on arable or livestock enterprises. This paper focuses on the integration of understorey crops and/or livestock within high value tree systems (e.g. apple orchards, olive groves, chestnut woodlands, and walnut plantations), and describes the components, structure, ecosystem services and economic value of ten case studies of this type of agroforestry across Europe. Although their ecological and socio-economic contexts vary, the systems share some common characteristics. The primary objective of the farmer is likely to remain the value of tree products like apples, olives, oranges, or nuts, or particularly high value timber. However there can still be production, environmental or economic benefits of integrating agricultural crops such as chickpeas and barley, or grazing an understorey grass crop with livestock. Three of the systems focused on the grazing of apple orchards with sheep in the UK and France. The introduction of sheep to apple orchards can minimise the need for mowing and provide an additional source of revenue. Throughout the Mediterranean, there is a need to improve the financial viability of olive groves. The case studies illustrate the possibility of intercropping traditional olive stands with chickpea in Greece, or the intercropping of wild asparagus in high density olive groves in Italy. Another system studied in Greece involves orange trees intercropped with chickpeas. Stands of chestnut trees in North-west Spain can provide feed for pigs when the fruit falls in November, and provide an excellent habitat for the commercial production of edible mushrooms. In Spain, in the production of high quality walnut trees using rotations of up to 50-60 years, there are options to establish a legume-based mixed pasture understorey and to introduce sheep to provide financial and environmental benefits.
\end{abstract}

Keywords: Apple, Orange, Olive, Chestnuts, Walnuts, Grazing 


\section{Introduction}

Agroforestry has been defined as "the integration of woody vegetation (first component) in at least two vertical layers on land, with the bottom layer providing an agricultural product such as crops or forage/pasture (second component) which may be consumed by animals (third component). The distribution of the woody vegetation can be uneven or evenly distributed and the woody component can deliver an agronomic product (fruit, forage) and some other ecosystem services" (Mosquera-Losada et al. 2016). In many agroforestry projects, the focus is on integrating trees within arable or livestock systems. There are also reviews of maintenance and improvement of established wood pasture and hedgerow systems of known cultural and biodiversity significance (Moreno et al. 2017). However an alternative approach is to integrate understorey crops or grazing within existing high value tree systems such fruit orchards, olive groves, or high value timber plantations (López-Díaz et al. 2013, 2014). This approach is defined as high value tree agroforestry and places primarily emphasis on the tree production and secondly to the intercrop and/or the livestock grazing in the system. Examples of high value fruit trees agroforestry systems include olive, carob, pine-nut, walnut, almond, chestnut, apple, and pear systems; examples of high value timber trees include walnut and wild cherry systems. Olive trees are one of the most important species in the Mediterranean regions (Camarsa et al. 2016) and apple trees are common in Atlantic and Continental regions (Robertson et al. 2012; Lebon 2016). Den Herder et al. (2017) report that agroforestry involving fruit, olive and nut trees cover about 1.05 million hectares in the EU, corresponding to about $0.2 \%$ of the territorial area. This excludes the area of agroforestry involving high value timber trees. The largest areas of agroforestry with fruit, olive and nut trees in Europe can be found in Spain and Italy, followed by Portugal and Greece (den Herder et al. 2017).

Research on the integration of crops and grazing with high value tree systems in Europe is limited despite the environmental benefits, the economic opportunities for additional revenue for the farmer, and the wide geographical opportunities of this type of agroforestry (den Herder et al. 2017). One focus of agroforestry research is to identify the combinations of trees and crops where competition for resources is minimised (Rolo and Moreno 2012; Talbot and Dupraz 2012). As there is a plethora of traditional intercropping practices in Europe (Jose et al. 2004; Eichhorn et al. 2006), the positive and negative effects of integrating crops or grazing with high value trees depends on site-specific characteristics. However with appropriate designs and practices, agroforestry within high value tree systems can increase profits for farmers and provide environmental benefits for society (EC 2011).

Starting in 2014, as part of the EU-sponsored 'AGFORWARD' project (Burgess et al. 2015), a participatory research approach was developed to understand the main challenges and innovations in integrating crops and grazing in high value tree systems. Within this project, ten stakeholders groups focused on such systems were created across different countries in Europe, with the aim of gathering information on, and describe the components, structure, ecosystem services and economic value of intercropping and/or grazing within high value tree systems in Europe, and the main constraints faced by such systems in order to design profitable and ecologically resilient systems. This paper reports the results emerged from the stakeholders groups along with existing bibliography on each case.

\section{Methods}

The ten stakeholder groups focused on the intercropping or grazing of high value trees such as apple (Burgess 2014; Corroyer 2014; McAdam 2014), olive (Pantera 2014a, 2014b; Rosati 2014), orange (Pantera 2014d), chestnut (Mosquera-Losada et al. 2014) and walnut trees (Moreno 2014) (Table 1). These stakeholder groups cover the North and South Mediterranean, and the North, Central, and Southern Atlantic agroclimatic zones. In the case of olives (Greece and Italy) and apples (UK and France), the same tree species were studied in different areas with opportunities to compare, exchange ideas, information and knowledge between countries. Even though an initial stakeholders' group was created for walnut in Greece (Pantera 2014c) and chestnut trees in Switzerland, these did not continue for local logistical reasons.

The stakeholder groups included farmers, breeders, foresters, landowners, representatives of regional and national associations, agricultural suppliers, extension services, NGOs, policy makers, and scientists. Each stakeholder group held an initial meeting, with a facilitated open discussion, to identify and prioritize the main challenges that farmers faced with the respective agroforestry system. These results are described in detail by Garcia de Jalon et al. (2017). Subsequent meetings and research focused on 
describing the components and the structure of the ten selected systems. Additionally, the facilitators worked with the stakeholders to identify possible innovations to overcome the challenges identified for their farms and territories and that could improve the profitability and ecological persistence of the system. In this paper, therefore, we report the results of this further work. Ecosystem services are presented based on the framework used by De Groot et al. (2002) that categorises the wider societal benefits and costs of ecological systems in terms of production, regulation, information, and habitat services. An economic evaluation of the systems is based on the criteria mentioned by Nair (1985).

\section{Results and Discussion}

The results of the review are discussed in terms of i) the components, ii) the structure, iii) the ecosystem services, and iv) the management and economic value of the studied systems.

\section{Components of agroforestry with high value trees}

The three potential components of an agroforestry system are the tree or woody component, the herbaceous vegetation such as agricultural crops or forage pasture species, and livestock (Nair 1985). Each of the systems studied had a woody and an understorey component, six of the ten systems involved sheep and one included pigs (Table 1 ).

In each of the systems, the tree component has an established economic value and, in most cases, they represent the major source of income for the farmer. In the three apple tree systems the principal source of income is from the sale of apples, the sale of olives or olive oil is the principal source of revenue in the three olive tree systems, oranges or chestnuts are important in two systems, and walnut or ash for timber was important in the remaining two systems (Table 1).

The trees will generally reduce the amount of light reaching the ground and this can reduce understory production (Mosquera Losada et al. 2009). However light competition can be minimised by the pruning of the trees, which is often undertaken to encourage air movement through the orchard to minimise disease or to maximise the production of high value knot-free timber. The tree heights within the selected systems ranged from $2 \mathrm{~m}$ for the bush apple orchards to $12 \mathrm{~m}$ in some timber plantations. A detailed description of the tree components follows below.

Apple trees (Malus domestica L.) were the focus of the stakeholder groups in Northern Ireland and England in the UK and in a group in Northern France (Table 1). Apple orchards are planted either to produce dessert apples or to produce apple juice that can also be used to produce cider. The structure of the trees can range from a short bush-like habit (less than $1 \mathrm{~m}$ of the trunk is side-pruned) to half standards (1-2 $\mathrm{m}$ ) or standard trees (pruned so that there are no side branches below a height of $2 \mathrm{~m}$ ). In cider orchards, because the initial product is apple juice, the appearance of the apples is less important than for dessert apples. The practice of grazing orchards is rare in the commercial desert apple orchards of Northern Ireland. The production of blemish free apples requires an intensive agrochemical programme which can have negative environmental effects (McAdam 2015). In that group, the stakeholders proposed that control of apple scab and a reduction in pesticide inputs/costs might be achieved by grazing sheep in the orchards. The logic is that sheep will eat apple leaves immediately as they fall to the ground, and help to decompose old leaves by trampling, thus reducing harbourage for the organism responsible (McAdam 2014). By contrast, grazing in cider apple orchards in England is a traditional practice (Hoare 1928) that is still practised on orchards with high-pruned apple trees (Burrough et al. 2010). Similarly in France, grazing of traditional orchards has long been a common practice and continues to be practiced on a considerable percentage of extant traditional orchards. However it is rare for commercial cider "bush" orchards to be grazed. Bush orchards are the dominant system used for cider apple production in France, with stocking density of about 600-1000 trees ha-1 with an inter-row spacing of about 5-5.5 $\mathrm{m}$ and an intra-row spacing of 2-2.5 m (Table 2) (Corroyer 2014). 
Table 1. Components of ten agroforestry systems with high value trees as identified by ten stakeholder groups

\begin{tabular}{|c|c|c|c|c|}
\hline System & $\begin{array}{l}\text { Tree } \\
\text { component }\end{array}$ & $\begin{array}{l}\text { Crop/ } \\
\text { understorey } \\
\text { component }\end{array}$ & $\begin{array}{l}\text { Animal } \\
\text { component }\end{array}$ & $\begin{array}{l}\text { Reference for initial } \\
\text { stakeholder report } \\
\text { and system } \\
\text { description }\end{array}$ \\
\hline $\begin{array}{l}\text { Grazed orchard in } \\
\text { England, UK }\end{array}$ & $\begin{array}{l}\text { Apple (Malus } \\
\text { domestica L.) }\end{array}$ & $\begin{array}{l}\text { Perennial } \\
\text { ryegrass (Lolium } \\
\text { perenne L.) } \\
\end{array}$ & $\begin{array}{l}\text { Sheep: Shropshire } \\
\text { breed }\end{array}$ & $\begin{array}{l}\text { Burgess (2014) } \\
\text { Burgess et al. (2016) }\end{array}$ \\
\hline $\begin{array}{l}\text { Grazed orchard in } \\
\text { Northern Ireland, } \\
\text { UK }\end{array}$ & $\begin{array}{l}\text { Apple cider variety: } \\
\text { Coet-de-linge, and } \\
\text { dessert variety: } \\
\text { Jonagold }\end{array}$ & $\begin{array}{l}\text { Perennial } \\
\text { ryegrass }\end{array}$ & $\begin{array}{l}\text { Sheep: mixed } \\
\text { breeds including } \\
\text { Texel, Belclare, } \\
\text { LLeyn and } \\
\text { Highlander }\end{array}$ & $\begin{array}{l}\text { McAdam (2014) } \\
\text { McAdam and Ward } \\
(2015)\end{array}$ \\
\hline $\begin{array}{l}\text { Grazed orchard in } \\
\text { France }\end{array}$ & Apple & $\begin{array}{l}\text { Perennial } \\
\text { ryegrass }\end{array}$ & $\begin{array}{l}\text { Sheep: Shropshire } \\
\text { breed }\end{array}$ & $\begin{array}{l}\text { Corroyer (2014) } \\
\text { Corroyer (2016) }\end{array}$ \\
\hline $\begin{array}{l}\text { Intercropping of } \\
\text { olive groves, } \\
\text { Molos, Greece }\end{array}$ & Olive (Olea europea) & $\begin{array}{l}\text { Cereals, maize, } \\
\text { grape vines, } \\
\text { vegetables, grass, } \\
\text { and chickpea } \\
\text { (Cicer arietinum) }\end{array}$ & Sheep & $\begin{array}{l}\text { Pantera (2014b) } \\
\text { Pantera et al (2016a) }\end{array}$ \\
\hline $\begin{array}{l}\text { Intercropping of } \\
\text { olive groves, } \\
\text { Kassandreia, } \\
\text { Greece }\end{array}$ & $\begin{array}{l}\text { Olive (Olea europea } \\
\text { L.), } \\
\text { Pear (Pyrus sp.), } \\
\text { Pines (Pinus halepensis } \\
\text { Mill.) }\end{array}$ & Wheat and barley & No animals & $\begin{array}{l}\text { Pantera (2014a) } \\
\text { Mantzanas et al. } \\
(2015)\end{array}$ \\
\hline $\begin{array}{l}\text { Intercropping in } \\
\text { olive orchard, Italy }\end{array}$ & Olive & $\begin{array}{l}\text { Asparagus } \\
\text { (Asparagus } \\
\text { acutifolius L.) } \\
\text { and bulbs } \\
\text { (Narcissus and } \\
\text { Tulipa species }\end{array}$ & No animals & $\begin{array}{l}\text { Rosati (2014) } \\
\text { Rosati and } \\
\text { Mantovani (2015) }\end{array}$ \\
\hline $\begin{array}{l}\text { Intercropping of } \\
\text { orange groves, } \\
\text { Greece }\end{array}$ & $\begin{array}{l}\text { Orange (Citrus } \\
\text { sinensis L.) }\end{array}$ & $\begin{array}{l}\text { Vegetables } \\
\text { (here chickpea } \\
\text { (Cicer arietinum } \\
\text { L.) }\end{array}$ & No animals & $\begin{array}{l}\text { Pantera (2014d) } \\
\text { Pantera et al. } \\
(2016 b)\end{array}$ \\
\hline $\begin{array}{l}\text { Grazing walnut } \\
\text { timber plantations } \\
\text { in Spain }\end{array}$ & $\begin{array}{l}\text { Hybrid walnut } \\
\text { (Juglans major x } \\
\text { regia) Mj209xRa }\end{array}$ & Grass species & $\begin{array}{l}\text { Sheep: Merina } \\
\text { breed }\end{array}$ & $\begin{array}{l}\text { Moreno (2014) } \\
\text { Moreno et al. } \\
(2015)\end{array}$ \\
\hline $\begin{array}{l}\text { Chestnut } \\
\text { agroforestry in } \\
\text { Galicia, Spain }\end{array}$ & $\begin{array}{l}\text { Chestnut } \\
\text { (Castanea sativa L.) }\end{array}$ & $\begin{array}{l}\text { Ulex sp., } \\
\text { Pteridium sp. } \\
\text { Rubus sp., and } \\
\text { mushrooms } \\
\end{array}$ & Pigs: Celtic breed & $\begin{array}{l}\text { Mosquera Losada } \\
\text { et al. (2014) } \\
\text { Fernandez Lorenzo } \\
\text { et al. (2016) }\end{array}$ \\
\hline $\begin{array}{l}\text { Traditional wood } \\
\text { pasture in France }\end{array}$ & $\begin{array}{l}\text { Ash (Fraxinus } \\
\text { excelsior L.) }\end{array}$ & Grass species & $\begin{array}{l}\text { Sheep (Lacaunes) } \\
\text { or cows (depending } \\
\text { on the region) }\end{array}$ & $\begin{array}{l}\text { Van Lerberghe and } \\
\text { Malignier (2015; } \\
\text { 2016) }\end{array}$ \\
\hline
\end{tabular}

Olive (Olea europea), considered to be the gift of Goddess Athena to the Athenians based on Greek mythology, is probably the most widespread cultivated tree in Mediterranean countries. It was the focus in the studied systems in Central Macedonia, Greece, one in Central Greece and one in Italy (Table 1). The olive tree is considered as one of the least demanding cultivated trees in terms of soil nutrients and hence it can be planted in poor, rocky areas with soils mostly derived from hard limestone (Gomez et al. 2003; Vossen 2007; Duarte et al. 2008). In fact many olive groves are found on steep mountain slopes which have been terraced with stone walls to hold the soil. 
Olive trees in Greece can be found either in monoculture orchards, or growing alone, in all parts of the country that have a mild Mediterranean climate. Quite often, however, they are grown with other trees such as carobs (mainly in Crete), almonds, walnuts, apricots, figs, poplars, and plums; often these trees are planted along the boundaries of the olive orchards. In the traditional systems, practically all olive trees came from wild plants which were grafted. Edible olives and olive oil are the main products of olive trees, while secondary products include fodder for animals and firewood. In some places, exquisite furniture and handicrafts are made of olive wood. Examples of crops established between and below olive trees include a) pasture for grazing animals such as sheep, cattle, goats, pigs or chickens, b) wheat and other cereals, maize, alfalfa, or grape vines, (c) vegetable crops, i.e. potatoes, melons, tomatoes, beans, onions, or fava beans, and (d) wild herbaceous vegetation, some plants of which are edible. Animals may graze on the spontaneous vegetation or on planted crops (ex. wheat or barley) (Papanastasis et al. 2009).

In Italy over one million ha of olive orchards risk large scale abandonment, since the removal of trees is prohibited, the olive oil price is relatively low and the de-coupling of subsidies from production have made harvesting unnecessary. The selection of the appropriate species and the development of targeted and innovative agronomic practices are important to improving the efficiency of agroforestry practices and the maximisation of ecosystem services (Tsonkova et al. 2012). Among the wide range of perennial species evaluated, wild asparagus (Asparagus acutifolius) holds high potential as a new crop, in combination with the olive tree (Table 1) (Rosati et al. 2009, Mantovani and Rosati 2014, Mantovani et al. 2016). Since the plant naturally grows in abandoned olive orchards, and the market for its spears is already established, its cultivation appears profitable. To optimise the land use and further diversify the outputs, other crops could be added to asparagus production in olive orchards. Bulb crops appear to be an interesting alternative to arable crops, since they are perennials like the asparagus (i.e. no soil tilling necessary), but their vegetative cycle occurs in winter and spring, leaving the soil bare during the summer and the olive harvest time in the fall.

Chestnut trees (Castanaea sativa Miller) comprise the woody component in a studied system in Galicia, Spain. Agroforestry with chestnut is a traditional land use system in the eastern part of the Lugo province in Galicia, in North West Spain (Table 1). Although chestnut groves are rarely intercropped (due to the low understorey production) or grazed (due to the fear of tree damage), the groves create a finegrained mosaic of land uses including cropland and forests (Fernández Lorenzo et al. 2015) (Table 2). However pig grazing does occur in some areas during the autumn and winter, where high slopes make chestnut harvesting unprofitable. Chestnut woodlands are also one of the best habitats for the commercial production of edible mushrooms (Mosquera-Losada et al. 2014). Chestnut groves are also very popular in most continental areas in Greece with grazing by sheep and goats being the most common traditional use. Chestnut production in Greece usually exceeds 15000 tonnes per year (ELSTAT 2015). 70\% of the production of some areas such as the Pelion was exported in Italy in 2015. In the prefecture there are two big chestnut forests that are popular for the production large size and high quality chestnuts. It is reported that an average annual production per tree can reach as much as $50-60 \mathrm{~kg}$ of chestnuts. Chestnuts can be considered organic since agrochemicals are rarely used. Besides harvesting the chestnuts, farmers use the area for the production of honey and dairy products from livestock grazing underneath the trees.

The stakeholder group focused on the intercropping of orange trees (Citrus sinensis L.) was based in Crete (Table 1), but orange cultivation is popular and traditional throughout Western Greece. Orange growers in Greece face the challenges of international competition from lower cost producers and from climate change. Orange groves with cypress windbreaks comprise one of the traditional Mediterranean landscapes especially in W. Greece and the island of Crete. Of the global annual production of 80 million tonnes of citrus fruit, 19 million tonnes come from the Mediterranean and 1.1 million tonnes from Greece. Greece is the $17^{\text {th }}$ of the 121 orange producing countries contributing by 805500 tonnes of the world total 71 million tonnes (FAOSTAT 2013). In the past, farmers in the Chania area of Crete cultivated crops between citrus trees after pollarding (Table 2). They also used cypress trees as windbreaks to protect the citrus trees from wind. However many farmers have removed the cypress trees from the windbreaks and have uprooted the citrus trees and replaced them with monoculture stands for higher profit. Only a few farmers still practice the agroforestry system of citrus trees with intercrops. This practice can help ensure an economic return each year until the tree canopy fully develops and excludes any form of intercropping. 
Most of the intercrops are vegetables. After crown development the intercrops are sometimes replaced by poultry production (Table 1 ).

In La Coruña, N. Spain, in a large area with walnut trees owned by the company "Bosques Naturales S.A.", grazing by sheep is used to control the competing herbaceous strata and provide extra products (Tables 1 \& 2) (Bosques Naturales 2017 and personal visit to the site). In Extremadura (Spain) in a 15-year old hybrid walnut (Juglans major x nigra mj 209xra) plantation, with a density of 333 trees ha-1 owned by the company Bosques Naturales S.A., two other experiments have been established: one for testing alternatives to the traditional mineral fertilization called "Fertilized walnut" and one with different techniques for controlling the competition of herbaceous strata behind trees hereafter called "Grazed walnut" (Moreno et al. 2014). In many continental parts of Greece farmers have traditionally integrated agricultural production with high value tree species such as walnut on the same plot. In this way they have ensured a steady economic return under variable weather conditions. A typical location in Eurytania, Central Greece, is characterized by walnut trees growing at the edge of fields of maize, dry beans, cereals and pasture (Pantera et al. 2014c). This agroforestry system is very popular throughout central Greece, Thessaly and Macedonia. Actually in W. Macedonia it is common to grow walnuts at the edge of agricultural fields of beans and, in one occasion, beans were cultivated between the rows of the trees. The production of the beans was much lower than those growing in the open but, as the farmer said, it is an additional production and income to the walnuts.

Finally, ash trees (Fraxinus excelsior L.) are planted on hedges around the fields and were studied as the woody component in a system in France (Table 1). In North-western France, pollarding is still a living practice linked to the management of the "bocage" landscape of "traditional" hedgerows on field boundaries (Bernard et al. 2006). In southern France, pollards are generally found as remnants of a formerly much more widespread practice. Generally, it is a traditional way to delimit the plots, to bring shade and fodder to livestock and restrict erosion. Trees are pollarded to increase the quantity of wood production during a short-term rotation (Table 2). The cutting tree height depends on the region. Grazing provides a means of maintaining a short sward and providing fodder for sheep. The sheep may be lambs which are being fattened or ewes that need to maintain body weight until the next lambing season (Tables 1 \& 2). Until the 1970s, ash trees were pollarded every 4 to 5 years in August or September. The leafy branches were gathered into bundles and stored in barns or simply left in the plots. Livestock was fed with dried leaves in January or February. Large branches were used as firewood (Métailié 2006). With the disappearance of farms in mountain areas, tree management and branches pollarding were abandoned. Humans have substantially altered the natural landscape. Extensive clearance was carried out to use the land for pasture or arable crops, but there are still areas of wood-pasture where land with trees is systematically grazed by domestic animals. Its structure consists of large open-grown or pollarded trees at various densities, in a matrix of grazed grassland and forest vegetation. Although pollarding was clearly an important part of the agrarian culture the trees are now largely overlooked. Due to mechanisation and intensification of agriculture, trees have been progressively removed from grasslands and traditional agroforestry systems have slowly disappeared. Currently, the large amount of branches biomass could make harvest economically worthwhile. Fuel and fire wood demand is high and growing in the touristic valleys of the Pyrenees. Encouragement needs to be given and awareness on pollards should be raised so that they can be maintained in landscapes. Pollarding is a way of getting a regular production from the trees (for example: wood-fuel or animal bedding) while also obtaining a revenue from the land underneath (Read 2006).

In Europe, the area of high value trees that is grazed is greater than the area that is intercropped (den Herder et al. 2017). Grass, with or without legumes, is the dominant understorey crop in the Atlantic and continental zone (Table 1) as it can maintain high yields when shaded, due to the focus on vegetative growth and its high biodiversity (Pardini et al. 2010). By contrast in Mediterranean areas, the potential understorey crop species is larger including cereals and horticultural crops such as wild asparagus, bulbs, mushrooms, and grapes (Table 1). This can be explained by the total and seasonal distribution of rainfall with dry summers and humid winters, as well as the soil type, that determine respectively the understory productivity (Mosquera-Losada et al. 2009) affecting cultural familiarity, management systems, and technology as well as the legacy. Asparagus and mushrooms are of particular interest as they are relatively shade-tolerant and there can be significant market demand for these products. 
Table 2. Structure of the high value tree agroforestry systems

\begin{tabular}{|c|c|c|c|c|c|c|c|}
\hline System & Strata* & $\begin{array}{l}\text { Spatial } \\
\text { arrangements }\end{array}$ & $\begin{array}{l}\text { Temporal } \\
\text { arrangement }\end{array}$ & $\begin{array}{l}\text { Tree } \\
\text { spacing }\end{array}$ & $\begin{array}{l}\text { Tree } \\
\text { height }\end{array}$ & $\begin{array}{l}\text { Tree } \\
\text { density }\end{array}$ & $\begin{array}{l}\text { Stocking } \\
\text { density }\end{array}$ \\
\hline $\begin{array}{l}\text { Grazed } \\
\text { orchard in } \\
\text { England, UK }\end{array}$ & $2 \mathrm{~V}$ & $\begin{array}{l}\text { Traditional } \\
\text { orchard with } \\
\text { trees in rows }\end{array}$ & $\begin{array}{l}\text { Sheep are removed } \\
56 \text { days before } \\
\text { apple harvest }\end{array}$ & $6 \mathrm{~m} \times 3 \mathrm{~m}$ & $6-7 m$ & $\begin{array}{l}500 \text { trees } \\
\text { ha }^{-1}\end{array}$ & $\begin{array}{l}20 \text { sheep } \\
\text { ha }^{-1}\end{array}$ \\
\hline $\begin{array}{l}\text { Grazed } \\
\text { orchard in } \\
\text { Northern } \\
\text { Ireland, UK }\end{array}$ & $2 \mathrm{~V}$ & $\begin{array}{l}\text { Bush orchard in } \\
\text { linear rows with } \\
\text { windbreaks }\end{array}$ & $\begin{array}{l}\text { Short-term grazing } \\
\text { on small plots; } \\
\text { sheep start in May, } \\
\text { removed in June, } \\
\text { and introduced in } \\
\text { Nov - Dec** }\end{array}$ & $\begin{array}{l}\text { Cider } \\
\text { variety } \\
5 \mathrm{~m} \times 2 \mathrm{~m} \\
\text { Dessert } \\
\text { variety } \\
4 \mathrm{~m} \times 1.5 \mathrm{~m}\end{array}$ & $\begin{array}{l}2-2.5 \\
m\end{array}$ & $\begin{array}{l}\text { Cider: } \\
900 \text { trees } \\
\text { ha }^{-1} \\
\text { Dessert: } \\
1485 \text { trees } \\
\text { ha }^{-1}\end{array}$ & $\begin{array}{l}\text { Over the } \\
\text { season } \\
\text { would be } \\
12-15 \\
\text { sheep ha-1 }\end{array}$ \\
\hline $\begin{array}{l}\text { Grazed } \\
\text { orchard in } \\
\text { France }\end{array}$ & $2 \mathrm{~V}$ & $\begin{array}{l}\text { «bush» orchard } \\
\text { in linear rows }\end{array}$ & $\begin{array}{l}\text { Sheep introducing } \\
\text { in April and } \\
\text { removed in mid- } \\
\text { November }\end{array}$ & $\begin{array}{l}5-5.5 \mathrm{mx} \\
2-2.5 \mathrm{~m}\end{array}$ & $5 \mathrm{~m}$ & $\begin{array}{l}600-1000 \\
\text { trees ha-1 }\end{array}$ & $\begin{array}{l}4 \text { sheep } \\
\mathrm{ha}^{-1}\end{array}$ \\
\hline $\begin{array}{l}\text { Intercropping } \\
\text { of olive } \\
\text { groves, } \\
\text { Molos, Greece } \\
\end{array}$ & $2 \mathrm{~V}$ & $\begin{array}{l}\text { Linear rows of } \\
\text { trees and in- } \\
\text { between } \\
\text { intercrops } \\
\end{array}$ & $\begin{array}{l}\text { Intercropping only } \\
\text { in spring-summer, } \\
\text { sheep from March } \\
\text { to November** }\end{array}$ & $10 \mathrm{~m} \times 10 \mathrm{~m}$ & $\sim 5 \mathrm{~m}$ & $\begin{array}{l}120 \text { trees } \\
\text { ha }^{-1}\end{array}$ & $\begin{array}{l}\text { Not } \\
\text { specified }\end{array}$ \\
\hline $\begin{array}{l}\text { Intercropping } \\
\text { of olive } \\
\text { groves, } \\
\text { Kassandreia, } \\
\text { Greece }\end{array}$ & $2 \mathrm{~V}$ & $\begin{array}{l}\text { Scattered and in } \\
\text { some cases linear } \\
\text { rows of trees }\end{array}$ & $\begin{array}{l}\text { Intercropping only } \\
\text { in spring-summer, } \\
\text { sheep \& goat } \\
\text { grazing from } \\
\text { March- } \\
\text { November** }\end{array}$ & $10 \mathrm{~m} \times 10 \mathrm{~m}$ & $\sim 8 \mathrm{~m}$ & $\begin{array}{l}100 \text { trees } \\
\text { ha }^{-1}\end{array}$ & - \\
\hline \multirow[t]{2}{*}{$\begin{array}{l}\text { Intercropping } \\
\text { in olive } \\
\text { orchards, Italy }\end{array}$} & $\begin{array}{l}2 \mathrm{~V} \text { and } \\
1 \mathrm{H}\end{array}$ & $\begin{array}{l}\text { Intercrops } \\
\text { between linear } \\
\text { rows of olive } \\
\text { trees: traditional } \\
\text { spacing }\end{array}$ & \multirow{2}{*}{$\begin{array}{l}\text { Intercropping with } \\
\text { permanent } \\
\text { evergreen } \\
\text { (asparagus) or with } \\
\text { fall-to-spring } \\
\text { vegetation (bulbs) } \\
\text { crops }\end{array}$} & $6 \mathrm{~m} \times 7 \mathrm{~m}$ & $5 \mathrm{~m}$ & $\begin{array}{l}238 \text { trees } \\
\text { ha }^{-1}\end{array}$ & \\
\hline & & $\begin{array}{l}\text { Super-high } \\
\text { density }\end{array}$ & & $4 \mathrm{~m} \times 1.5 \mathrm{~m}$ & $2.5 \mathrm{~m}$ & $\begin{array}{l}1666 \text { trees } \\
\text { ha }^{-1}\end{array}$ & \\
\hline $\begin{array}{l}\text { Intercropping } \\
\text { of orange } \\
\text { groves }\end{array}$ & $2 \mathrm{~V}$ & $\begin{array}{l}\text { Scattered and in } \\
\text { some cases linear } \\
\text { rows of trees }\end{array}$ & $\begin{array}{l}\text { Intercropping only } \\
\text { in spring-early } \\
\text { summer }\end{array}$ & $10 \mathrm{~m} \times 10 \mathrm{~m}$ & $\sim 5 \mathrm{~m}$ & $\begin{array}{l}100 \text { trees } \\
\text { ha }^{-1}\end{array}$ & - \\
\hline $\begin{array}{l}\text { Grazed } \\
\text { walnut timber } \\
\text { plantations in } \\
\text { Spain }\end{array}$ & $2 \mathrm{~V}$ & $\begin{array}{l}\text { Linear rows of } \\
\text { trees }\end{array}$ & $\begin{array}{l}\text { Year-round grazing } \\
\text { except the lambing } \\
\text { period }\end{array}$ & $6 \mathrm{~m} \times 5 \mathrm{~m}$ & $\sim 12 \mathrm{~m}$ & $\begin{array}{l}333 \text { trees } \\
\text { ha }^{-1}\end{array}$ & 1 \\
\hline \multirow[t]{2}{*}{$\begin{array}{l}\text { Chestnut } \\
\text { agroforestry } \\
\text { in Galicia, } \\
\text { Spain }\end{array}$} & $\begin{array}{l}2 \mathrm{H} \text { and } \\
1 \mathrm{~V}\end{array}$ & $\begin{array}{l}\text { Scattered trees } \\
\text { with full canopy } \\
\text { cover }\end{array}$ & $\begin{array}{l}\text { April-September } \\
\text { in the } 50 \text { years } \\
\text { old stand and } \\
\text { October- } \\
\text { December in the } \\
\text { older stand }\end{array}$ & $\begin{array}{l}\text { Scattered } \\
\text { trees }\end{array}$ & $\begin{array}{l}10-20 \\
m\end{array}$ & $\begin{array}{l}100-150 \\
\text { trees ha-1 }\end{array}$ & $\begin{array}{l}1.5 \text { celtic } \\
\text { pigs ha }^{-1}\end{array}$ \\
\hline & $2 \mathrm{H}$ & & $\begin{array}{l}\text { Whole year } \\
\text { around }\end{array}$ & $\begin{array}{l}3 \mathrm{~m} \times 3 \mathrm{~m} \\
\text { and } 5 \mathrm{~m} \times 5 \\
\mathrm{~m}\end{array}$ & $\ldots$ & $\begin{array}{l}1111-400 \\
\text { trees ha-1 }\end{array}$ & - \\
\hline $\begin{array}{l}\text { Bordure trees } \\
\text { in South- } \\
\text { West France }\end{array}$ & $\begin{array}{l}\text { Multiple } \\
\text { H \& V }\end{array}$ & $\begin{array}{l}\text { Boundary } \\
\text { (Hedges around } \\
\text { fields) }\end{array}$ & $\begin{array}{l}\text { Sheep introduced } \\
\text { in April }\end{array}$ & & & & $\begin{array}{l}\text { Not } \\
\text { specified }\end{array}$ \\
\hline
\end{tabular}

* Strata are defined in terms of the number of vertical $(\mathrm{V})$ and horizontal $(\mathrm{H})$ strata.

**: Depending on weather conditions 
Based on the reports of the stakeholders' groups, the principal livestock species is sheep (Table 1). One exception is the use of an autochthonous pig breed in an extensive chestnut system in Galicia in northwest Spain (Table 1). Agroforestry with chestnut is a traditional land use system in the area but also in many other places as in Greece. In Greece, sheep grazing of chestnut groves is traditionally practiced throughout the year with the only exception of the time of chestnut collection (Pantera and Mouflis 1996). Because of the commercial importance of the trees in high value tree systems, it is critical that the chosen animal species and breed do not damage the trees. Indeed, identifying animal species and breeds that have only minor effects on the trees was one of the main goals identified by stakeholders (Pantera et al. 2015). Tree damage can also be minimised by using the generally low stock densities, as done in most of these systems.

\section{Structure of agroforestry with high value tree systems}

In terms of vertical spatial arrangement, most of the systems are arranged in two strata (Table 2). The focus on only two strata is common in European agroforestry on farmland, whereas elsewhere, there can be more strata in the oasis systems in North Africa or home-gardens. An advantage of a two strata, rather than a greater number, is that management and mechanisation is less complex. It can also be easier to ensure that the seasonal cycle of the capture of solar radiation, water or nutrients by the tree and the understorey is complementary, minimising competition as far as possible. In some cases, for example in the case of High-density olive trees, the substantial light interception by the trees means that the understorey crop must be shade tolerant. Two shade tolerant species included in the studies are asparagus and mushrooms (Table 2). This practice may enhance farmer's income in areas with market demand for these products.

In terms of horizontal spatial arrangements, the traditional olive systems in Greece, the chestnut in Spain, and the pollard system in France, comprise scattered trees, whilst the trees in the apple and citrus orchards, the commercial olive grove in Italy, and the walnut plantations are planted in linear rows (Table 2). The use of linear tree rows can facilitate the use of machinery and thereby reduce labour costs. Tree density is generally lower in the traditional systems, for example scattered trees down to a spacing of $10 \mathrm{~m}$ $x 10 \mathrm{~m}$, whereas the recently planted apple and olive systems have inter-row and intra-row spacing as low as $4 \mathrm{~m} \times 1.5 \mathrm{~m}$ (Table 2). Hence the tree densities range from less than 100 trees ha-1 to 1666 trees ha ${ }^{-1}$ in a super high-density olive plantation. Because of the impact on labour costs and intercrop yields, many of the stakeholder groups identified tree spacing and arrangement as a key area for research (Pantera et al. 2015).

In terms of their temporal arrangement (Nair 1985), the grazed apple orchard systems are primarily intermittent as the sheep are removed prior to apple harvest. By contrast the grazed system with walnut trees in Spain is coincident i.e. the sheep are maintained in the field during the whole year. The agrosilvopastoral olive system in Molos, Greece, is also a coincident system in that sheep are introduced after the crop component is harvested. By contrast the orange agroforestry system is a concomitant system i.e. the understorey crop is maintained for only part of the tree rotation when the canopy cover is low. Each of the studied systems appears to allow continuous long-term production, in that they use the same crop and animal components over time in a repeating cycle, based on familiar traditional knowledge. This is important as it can provide a constant cycle of income for the farmer.

\section{Ecosystem services of agroforestry with high value trees}

Each of the studied agroforestry systems is considered to promote a greater diversity of species than the corresponding monoculture orchard or plantation system. For example the biodiverse Galician chestnut system (Mosquera-Losada et al. 2016) belongs to the Natura 2000 network, is a priority area for birds, and is part of the recovery plan for the local bear population. The increase in biodiversity can help support provisioning, regulating, and cultural ecosystem services that can enhance human wellbeing (Table 3 ). 
Table 3. Provisioning, regulating and cultural ecosystem services of agroforestry with high value trees

\begin{tabular}{|c|c|c|c|c|c|c|c|c|c|c|c|c|c|c|c|}
\hline \multirow[b]{2}{*}{ System } & \multicolumn{4}{|c|}{ Provisioning } & \multicolumn{5}{|c|}{ Regulating } & \multicolumn{6}{|c|}{ Cultural } \\
\hline & $\begin{array}{l}\text { 꿍 } \\
\stackrel{0}{\varrho}\end{array}$ & $\begin{array}{l}-1 \\
\overline{3} \\
\frac{1}{0} \\
\frac{1}{1}\end{array}$ & 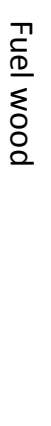 & 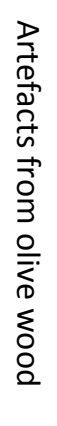 & 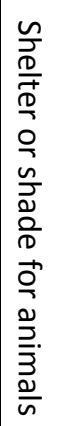 & 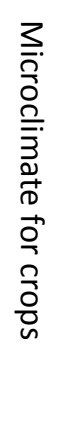 & 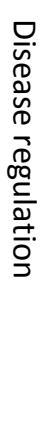 & 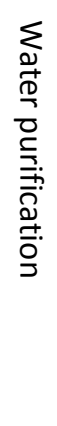 & 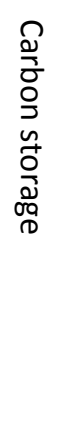 & 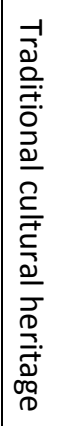 & 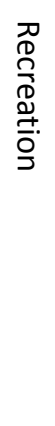 & 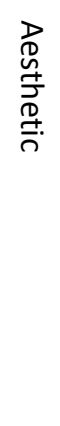 & 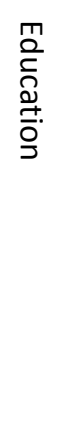 & 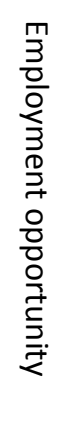 & 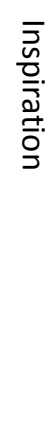 \\
\hline $\begin{array}{l}\text { Grazed orchard in } \\
\text { England }\end{array}$ & $\begin{array}{l}\text { Apple, cider, } \\
\text { meat }\end{array}$ & & $\checkmark$ & & $\checkmark$ & & $?$ & & $\checkmark$ & $\checkmark$ & & $\checkmark$ & $\checkmark$ & $\checkmark$ & \\
\hline $\begin{array}{l}\text { Grazed orchard in } \\
\text { Northern Ireland }\end{array}$ & $\begin{array}{l}\text { Apples, cider, } \\
\text { meat }\end{array}$ & & $\checkmark$ & & $\checkmark$ & & $?$ & & $\checkmark$ & $\checkmark$ & & $\checkmark$ & $\checkmark$ & $\checkmark$ & \\
\hline $\begin{array}{l}\text { Grazed orchard in } \\
\text { France }\end{array}$ & $\begin{array}{l}\text { Apple, cider, } \\
\text { meat, dairy } \\
\text { products }\end{array}$ & & $\checkmark$ & & $\checkmark$ & & $?$ & & $\checkmark$ & $\checkmark$ & & $\checkmark$ & $\checkmark$ & $\checkmark$ & \\
\hline $\begin{array}{l}\text { Pollard boundary } \\
\text { trees in France }\end{array}$ & $\begin{array}{l}\text { Meat, dairy } \\
\text { products }\end{array}$ & & & & $\checkmark$ & & & $\checkmark$ & $\checkmark$ & $\checkmark$ & & $\checkmark$ & $\checkmark$ & $\checkmark$ & \\
\hline $\begin{array}{l}\text { Intercropping of } \\
\text { olive groves, Molos } \\
\text { in Greece }\end{array}$ & $\begin{array}{l}\text { Olives, olive } \\
\text { oil, herbs, } \\
\text { vegetables, } \\
\text { meat, dairy } \\
\text { product }\end{array}$ & & $\checkmark$ & $\checkmark$ & & & & & $\checkmark$ & $\checkmark$ & $\checkmark$ & $\checkmark$ & $\checkmark$ & $\checkmark$ & $\checkmark$ \\
\hline $\begin{array}{l}\text { Intercropping of } \\
\text { olive groves, } \\
\text { Kassandreia, } \\
\text { Greece }\end{array}$ & $\begin{array}{l}\text { Olives, olive } \\
\text { oil, } \\
\text { vegetables, } \\
\text { meat, dairy }\end{array}$ & & $\checkmark$ & & & & & $\checkmark$ & $\checkmark$ & $\checkmark$ & $\checkmark$ & $\checkmark$ & $\checkmark$ & $\checkmark$ & $\sqrt{ }$ \\
\hline $\begin{array}{l}\text { Intercropping in } \\
\text { olive orchards, Italy }\end{array}$ & $\begin{array}{l}\text { Olives, olive } \\
\text { oil, asparagus, } \\
\text { flowers }\end{array}$ & & $\checkmark$ & $\checkmark$ & & $\checkmark$ & & $\checkmark$ & $\checkmark$ & $\checkmark$ & $\checkmark$ & $\checkmark$ & $\checkmark$ & $\checkmark$ & $\sqrt{ }$ \\
\hline $\begin{array}{l}\text { Intercropping of } \\
\text { orange groves, } \\
\text { Greece }\end{array}$ & $\begin{array}{l}\text { Oranges, } \\
\text { herbs }\end{array}$ & & $\checkmark$ & & & $\checkmark$ & $\checkmark$ & $\checkmark$ & $\checkmark$ & $\checkmark$ & $\checkmark$ & $\checkmark$ & $\checkmark$ & $\checkmark$ & $\sqrt{ }$ \\
\hline $\begin{array}{l}\text { Grazing walnut } \\
\text { timber plantations, } \\
\text { Spain }\end{array}$ & $\begin{array}{l}\text { Walnuts, } \\
\text { meat, dairy } \\
\text { products }\end{array}$ & $\checkmark$ & $\checkmark$ & & $\checkmark$ & & $\checkmark$ & $\checkmark$ & $\checkmark$ & $\checkmark$ & & $\checkmark$ & $\checkmark$ & $\checkmark$ & \\
\hline \multirow{2}{*}{$\begin{array}{l}\text { Chestnut } \\
\text { agroforestry in } \\
\text { Galicia, Spain }\end{array}$} & $\begin{array}{l}\text { Chestnuts, } \\
\text { meat }\end{array}$ & $\checkmark$ & $\checkmark$ & & $\checkmark$ & & $\checkmark$ & $\checkmark$ & $\checkmark$ & $\checkmark$ & $\checkmark$ & $\checkmark$ & $\checkmark$ & $\checkmark$ & $\sqrt{ }$ \\
\hline & $\begin{array}{l}\text { Chestnuts, } \\
\text { mushrooms }\end{array}$ & & & & & $\checkmark$ & & $\checkmark$ & $\checkmark$ & $\checkmark$ & $\checkmark$ & $\checkmark$ & $\checkmark$ & $\checkmark$ & $\sqrt{ }$ \\
\hline
\end{tabular}

All systems were considered to provide supporting services such as primary production, nutrient cycling, and soil protection from erosion.

The apple, olive, walnut, and chestnut systems can all provide a primary food product from the trees (olives, apples, nuts, chestnuts) and, even with grazing or intercropping, this is likely to remain the primary focus of the farmer. The exception is the walnut plantation system where the primary aim is high quality timber. The inclusion of an understorey crop allows the production of additional food (such as vegetables), and the addition of grazing cows, sheep or pigs, allows the production of meat and dairy products (Table 3 ). The only exception is the French pollard system where the primary food product is meat and cheese (Table 3). In South France pollards are generally found as remnants of a formerly more widespread practice (Van Lerberghe and Malignier 2015). In these wood-pastures the land with the trees is systematically grazed 
by domestic animals. In each system, fuelwood is also a potential product that is receiving increasing emphasis. In the case of olive trees, the wood is also used for local crafts and the production of various artefacts. In the Galician chestnut system (Mosquera-Losada et al. 2016), chestnut products are recognised under the label of Protected Geographical Indication (PGI) and are exported to selected markets in Europe. Chestnut woodlands are one of the best habitats for the commercial production of edible mushroom and this was also one of the main innovations identified by the local stakeholders (Fernández-Lorenzo et al. 2015).

The agroforestry systems also provide regulating ecosystem services such as microclimate regulation (Table 3). In Mediterranean areas, the trees can shade and shelter livestock from high temperatures during the summer months. In Atlantic areas, the trees can provide shelter from cold temperatures in the winter. Improvements in water quality and reduction of runoff can also be important at a catchment scale. Increased levels of carbon sequestration, stored in the above- and below-ground biomass of the trees, also contribute to global climate mitigation. Other regulating services include disease regulation and pest control, both issues of concern to the stakeholders (Pantera et al. 2015).

In addition to the above, agroforestry for high value tree systems also provide a variety of cultural services (Table 3). These include improved landscape aesthetics, increased employment and education opportunities, and maintenance of cultural heritage. As Isted (2005) mentions, traditional agroforestry systems are an important part of the culture and heritage of many European areas, and in such areas they are viewed as systems that need to be preserved and sustainably managed. All systems were considered by the stakeholders to provide supporting services such as primary production, nutrient cycling and soil protection from erosion (Table 3).

\section{Management and the economic value of agroforestry with high value tree systems}

Agroforestry systems and practices need to be financially viable and socially acceptable to farmers (Graves et al. 2007, 2008, 2017). Each system in this study was commercially managed, with the exception of the French subsistence system (Table 4). As previously presented, the economic value of the apple, olive, orange, chestnut and walnut systems are primarily based on fruit or nut production, whilst the production of high value timber is also fundamental to the walnut system. It should be noted that ash (Fraxinus sp.) is included here due to its high timber value and its use as a forage tree. Even if wood is not the major product from apple, olive and orange trees, farmers still take advantage from pruning material as firewood or even first material for artefacts (Table 4).

Across the ten studied systems, the application of agrochemicals ranged from minimal (as in the lowinput apple orchard system in England) to the high use of chemical pesticides in the intercropping of olive groves in Kassandreia, Greece (Table 4). High levels of agrochemicals, which are typically applied mechanically, are likely to be associated with high mechanisation costs (Tables 2 \& 4). As already discussed, trees grown in rows allow a relatively easy use of machinery in-between the trees.

One of the significant inputs in many agroforestry systems is the labour required. The actual and the perceived "cost" of labour vary between countries and farms. It is possible that some farmers do not see time spent on the farm as a cost but view it as a livelihood strategy or a way of life, and this has implications for the uptake and sustainability of such systems. On a general basis, as shown in Table 4, trees structured in lines allow the use of machinery that, based on the level of inputs, can produce high outputs for commercial use. It is noteworthy that systems with low inputs or level of mechanisation, such as chestnuts in Spain, can deliver high outputs (Table 4). In a walnut intercropped and grazed system in Greece (Pantera et al. 2014c), the most negative issue was the low cash flow from the system. Generally, the small land area per property, such as in Greece, is not sufficient for high income, especially in this region where the growing season is short. High taxes and tight regulations concerning land use and management procedures posed by the government represent an obstacle to farmers and may affect the viability of the system. 
Table 4. Economic values associated with High Value Trees agroforestry systems

\begin{tabular}{|c|c|c|c|c|c|}
\hline System & $\begin{array}{l}\text { Agrochemical } \\
\text { inputs }\end{array}$ & Mechanization level & Labour & Outputs & Goal* \\
\hline $\begin{array}{l}\text { Grazed orchard } \\
\text { in England and } \\
\text { Wales }\end{array}$ & $\begin{array}{l}\text { Case study system } \\
\text { does not use } \\
\text { fungicide for scab } \\
\text { control }\end{array}$ & $\begin{array}{l}\text { Medium; Mowing } \\
\text { can be reduced by } \\
\text { use of sheep }\end{array}$ & $\begin{array}{l}\text { High: Sheep may } \\
\text { reduce mowing } \\
\text { costs; but labour } \\
\text { needed to manage } \\
\text { sheep }\end{array}$ & $\begin{array}{l}\text { 12-50 t/year/ha } \\
\text { apple) } \\
\text { About } 20 \text { ewes per } \\
\text { hectare with } 2 \\
\text { lambs produced } \\
\text { per ewe }\end{array}$ & $\mathrm{C}$ \\
\hline $\begin{array}{l}\text { Grazed orchard } \\
\text { in Northern } \\
\text { Ireland }\end{array}$ & $\begin{array}{l}\text { High use of } \\
\text { pesticides }\end{array}$ & $\begin{array}{l}\text { High: mowing for } \\
\text { grass and chemicals } \\
\text { for pest control }\end{array}$ & $\begin{array}{l}\text { High (mowing, } \\
\text { spraying, pruning, } \\
\text { harvesting, sheep } \\
\text { herding) }\end{array}$ & 30-45 t ha-1 apple & C \\
\hline $\begin{array}{l}\text { Grazed } \\
\text { orchards in } \\
\text { France }\end{array}$ & $\begin{array}{l}\text { Low in pesticides \& } \\
\text { fertilizers (cattle } \\
\text { manure), reduced } \\
\text { mowing }\end{array}$ & $\begin{array}{l}\text { High: mowing for } \\
\text { grass and chemicals } \\
\text { for pest control }\end{array}$ & $\begin{array}{l}\text { High (mowing, } \\
\text { spraying, pruning, } \\
\text { harvesting, sheep } \\
\text { herding) }\end{array}$ & $\begin{array}{l}25-35 \text { t/year } \\
\text { apple }\end{array}$ & $\mathrm{C}$ \\
\hline $\begin{array}{l}\text { Pollarded } \\
\text { boundary trees } \\
\text { in France }\end{array}$ & Low & Low (tree pollarding) & $\begin{array}{l}\text { Low (pollarding, } \\
\text { sheep herding) }\end{array}$ & Medium (cheese) & $S-1$ \\
\hline $\begin{array}{l}\text { Intercropping of } \\
\text { olive groves, } \\
\text { Molos, Greece }\end{array}$ & $\begin{array}{l}\text { Low (chemicals }-\mathrm{Cu}- \\
\text { for olive pests once a } \\
\text { year, } \mathrm{N} \text { fertilisation) }\end{array}$ & $\begin{array}{l}\text { High: pruning, } \\
\text { cultivation for } \\
\text { intercrops and } \\
\text { chemicals for pest } \\
\text { control }\end{array}$ & $\begin{array}{l}\text { High (pruning, } \\
\text { spraying, ploughing, } \\
\text { cultivation \& } \\
\text { planting, harvesting, } \\
\text { sheep herding) }\end{array}$ & $\begin{array}{l}\text { Olive production } \\
\text { approx. } 2.3 \mathrm{t} / \mathrm{ha} \text {, } \\
\text { chickpeas: } 2 \mathrm{t} / \mathrm{ha} \\
\text { oregano: } 0.97-1.8 \\
\text { t/ha }\end{array}$ & $C \& S$ \\
\hline $\begin{array}{l}\text { Intercropping of } \\
\text { olive groves, } \\
\text { Kassandreia, } \\
\text { Greece }\end{array}$ & $\begin{array}{l}\text { High (pesticides, } N \\
\text { fertilisation) }\end{array}$ & $\begin{array}{l}\text { High: pruning, } \\
\text { cultivation for } \\
\text { intercrops and } \\
\text { chemicals for pest } \\
\text { control }\end{array}$ & $\begin{array}{l}\text { High (pruning, } \\
\text { spraying, ploughing, } \\
\text { cultivation \& } \\
\text { planting, harvesting,) }\end{array}$ & $\begin{array}{l}\text { Olive production } \\
\text { approx. } 2.3 \mathrm{t} / \mathrm{ha} \text {, } \\
\text { chickpeas: } 2 \mathrm{t} / \mathrm{ha}\end{array}$ & $C \& S$ \\
\hline $\begin{array}{l}\text { Intercropping in } \\
\text { olive orchards, } \\
\text { Italy }\end{array}$ & $\begin{array}{l}\text { Medium (N P K } \\
\text { fertilisation + pest } \\
\text { control (Peacock eye } \\
\text { disease and olive fly) }\end{array}$ & $\begin{array}{l}\text { High: harvesting, } \\
\text { cultivation for } \\
\text { intercrops and } \\
\text { chemicals for pest } \\
\text { control }\end{array}$ & $\begin{array}{l}\text { High (pruning, } \\
\text { spraying, cultivation } \\
\text { \& planting, } \\
\text { harvesting) }\end{array}$ & $\begin{array}{l}\text { Olive production } \\
\text { approx. } 6-12 \mathrm{t} / \mathrm{ha} \text {, } \\
\text { asparagus } 0.5 \mathrm{t} / \mathrm{ha}\end{array}$ & $C \& S$ \\
\hline $\begin{array}{l}\text { Intercropping of } \\
\text { orange groves, } \\
\text { Greece }\end{array}$ & $\begin{array}{l}\text { High (pesticides, } N \\
\text { fertilisation) }\end{array}$ & $\begin{array}{l}\text { High: pruning, } \\
\text { cultivation for } \\
\text { intercrops and } \\
\text { chemicals for pest } \\
\text { control }\end{array}$ & $\begin{array}{l}\text { High (pruning, } \\
\text { spraying, cultivation } \\
\text { \& planting, } \\
\text { harvesting) }\end{array}$ & $\begin{array}{l}\text { Orange production } \\
\text { approx. } 25 \mathrm{t} / \mathrm{ha}, \\
\text { chickpeas: } 2 \mathrm{t} / \mathrm{ha}\end{array}$ & $C \& S$ \\
\hline $\begin{array}{l}\text { Non-grazed } \\
\text { walnut timber } \\
\text { plantations, } \\
\text { Spain } \\
\end{array}$ & $\begin{array}{l}\text { High (energy, } \\
\text { pesticides \& } \\
\text { fertilizers) }\end{array}$ & $\begin{array}{l}\text { High: mowing for } \\
\text { grass, chemicals for } \\
\text { pest control, } \\
\text { fertilization }\end{array}$ & $\begin{array}{l}\text { High (ploughing, } \\
\text { spraying, pruning, } \\
\text { harvesting) }\end{array}$ & High (timber) & $\mathrm{C}$ \\
\hline $\begin{array}{l}\text { Grazed walnut } \\
\text { timber } \\
\text { plantations }\end{array}$ & Low (fertilizers) & Low: fertilization & $\begin{array}{l}\text { High } \\
\text { (pruning, harvesting, } \\
\text { sheep herding) }\end{array}$ & $\begin{array}{l}\text { High (timber, meat } \\
\text { and cheese) }\end{array}$ & $\mathrm{C}$ \\
\hline \multirow[t]{2}{*}{$\begin{array}{l}\text { Chestnut } \\
\text { agroforestry in } \\
\text { Galicia, Spain }\end{array}$} & none & none & Low & $\begin{array}{l}\text { High (chestnuts } \\
\left(2-2.5 \mathrm{t} \mathrm{ha}^{-1}\right) \\
\text { meat, fuel wood) }\end{array}$ & $\mathrm{C}$ \\
\hline & none & none & Low & $\begin{array}{l}0.2 \mathrm{tha}^{-1} \\
\text { mushroom } \\
\text { production }\end{array}$ & $\mathrm{C}$ \\
\hline
\end{tabular}

*The goals of the systems are indicated as commercial (C), intermediate (I), or subsistence (S) 


\section{Conclusions}

In many agroforestry projects, the focus is on introducing trees to arable or livestock farms. This paper focuses on the introduction of intercrops or grazing to high value tree systems such as apple orchards, olive and citrus groves, and high value chestnut and walnut stands. According to the stakeholder groups' inputs, most of these tree species can provide farmers with a regular cycle of revenue from fruits or nuts, although in the case of walnut trees the primary source of revenue can be high value timber. In many situations, the stakeholders believed that there are opportunities to integrate trees with additional understorey crops or grass and livestock, with either financial (related to the extra products provided, or the reduced management required for mechanical operations) and/or societal benefits (such as improved carbon sequestration for climate regulation, reduced water pollution, or improved aesthetic benefits of the landscape). These systems, most with a traditional base, provide a promising land management option that should be promoted and conserved within the framework of sustainable management and local development as a promising land use to address environmental problems such as climate change. Among the research and action priorities that can be identified by this paper are the need to further identify and study existing successful intercropping combinations or new and modern ones, to acknowledge the role of HVT systems within the framework of climate-smart agriculture. Finally the wider use of agroforestry with high value trees in Europe can be promoted through successful on-farm demonstrations, agroforestry education for existing farmers, and the inclusion of agroforestry in tertiary level agricultural and forestry curricula.

\section{Acknowledgements}

We are thankful for the responses from a range of stakeholders who spared their time in meetings during 2014. The AGFORWARD project (Grant Agreement $N^{\circ}$ 613520) is co-funded by the European Commission, Directorate General for Research \& Innovation, within the 7th Framework Programme of RTD, Theme 2 Biotechnologies, Agriculture \& Food. This research has been co-funded by the Hellenic Ministry of Education, Research and Religion, General Secretariat for Research and Technology.

\section{References}

Bernard V, Renaudin S, Marguerie D (2006) Evidence of Trimmed Oaks (Quercus Sp.) in North Western France during the Early Middle Ages (9th-11th Centuries AD). Charcoal Analysis: New Analytical Tools and Methods for Archaeology. BAR Int Ser 1483: 103-108.

Bosques Naturales (2017) LA MOTA, ORXAL, SENDELLE, http://bosquesnaturales.com/finca/la-motaorxal-sendelle/

Burgess PJ, Crous-Duran J, den Herder M, Dupraz C, Fagerholm N, Freese D, Garnett K, Graves AR, Hermansen JE, Liagre F, Mirck J, Moreno G, Mosquera-Losada MR, Palma JHN, Pantera A, Plieninger T, Upson M (2015) AGFORWARD Project Periodic Report: January to December 2014. Cranfield University: AGFORWARD. http://www.agforward.eu/index.php/en/news-reader/id-27-february2015.html

Burgess PJ, Upson M, Graves A, Garcia de Jalon S (2016) System Report: Grazed Orchards in England and Wales. April 2016. 23 pp. http://www.agforward.eu/index.php/en/Grazed Orchards.html

Burgess PJ (2014) Initial Stakeholder Meeting Report: Grazed Orchards in the UK. 18 July 2014. 8 pp. Available online: http://www.agforward.eu/index.php/en/Grazed Orchards.html

Burrough AE, Oines CM, Oram SP, Robertson HJ (2010) Traditional Orchard Project in England - The creation of an inventory to support the UK Habitat Action Plan. London.

Camarsa G, Gardner S, Jones W, Eldridge J, Hudson T, Thorpe E, O'Hara E (2016) LIFE among the olives: Good practice in improving environmental performance in the olive oil sector. LIFE report available on

line: http://ec.europa.eu/environment/life/publications/lifepublications/lifefocus/documents/oliveoil.p $\underline{\mathrm{df}}$

Corroyer N (2016) System Report: Grazed Orchards in France. January 2016. 15 pp. 
http://www.agforward.eu/index.php/en/grazed-orchards-in-france.html

Fernández Lorenzo JL, Rigueiro Rodríguez A, Ferreiro Domínguez N, González Hernández P, Mosquera Losada MR (2016). System Report: Chestnut Agroforestry in Spain. January 2016. 13 pp. http://www.agforward.eu/index.php/en/chestnut-agroforestry-in-galicia-spain.html

Corroyer N (2014) Initial Stakeholder Meeting Report: Grazed Orchards in France. 1 December 2014. 8 pp. Available online: http://www.agforward.eu/index.php/en/grazed-orchards-in-france.html

De Groot RS, Wilson MA, Boumans RMJ (2002) A typology for the classification, description and valuation of ecosystem functions, goods and services. Ecological Economics 41: 393-408.

den Herder M, Moreno G, Mosquera-Losada RM, Palma J H, Sidiropoulou A, Freijanes Santiago JJ, CrousDuran J, Paulo JA, Tomé M, Pantera A, Papanastasis VP, Mantzanas K, Pachana P, Papadopoulos A, Plieninger T, Burgess PJ (2017) Current extent and stratification of agroforestry in the European Union. Agriculture, Ecosystems \& Environment, 241, 121-132.

Duarte F, Jones N, Fleskens L (2008) Traditional olive orchards on sloping land: Sustainability or abandonment? Journal of Environmental Management 89(2): 86-98.

EC (European Commission) (2011) A Resource-Efficient Europe - Flagship initiative under the Europe 2020 Strategy. COM (2011) 21

Eichhorn MP, Paris P, Herzog F, Incoll LD, Liagre F, Mantzanas K, Mayus M, Moreno G, Papanastasis VP, Pilbeam DJ, Pisanelli A, Dupraz C (2006) Silvopastoral systems in Europe - past, present and future prospects. Agroforestry Systems 67: 29-50

ELSTAT (2015) Annual Agricultural Statistical Survey of year 2012. Hellenic Statistical Authority, http://www.statistics.gr/en/statistics/agr, visited at 1/16/2016

FAOSTAT 2013, http://faostat3.fao.org/download/Q/QC/E, cited at January 4, 2016.

Fernández Lorenzo JL, Rigueiro Rodríguez A, Ferreiro-Domínguez N, González-Hernández P, Burgess P, Mosquera Losada R (2015) Research and Development protocol for Chestnut Agroforestry in Spain. Available on line: https://www.agforward.eu/index.php/en/chestnut-agroforestry-in-galiciaspain.html?file=files/agforward/documents/WP3 ES chestnuts protocol.pdf

Garcia de Jalon S, Burgess PJ, Graves A, Moreno G, McAdam J, Pottier E, Novak S, Bondesan V, Mosquera Losada MR, Crous-Duran J, Palma JHN, Paulo J, Oliveira TS, Cirou E, Hannachi Y, Pantera A, Wartelle R, Kay S, Malignier N, Van Lerberghe P Tsonkova P, Mirck J, Rois M, Kongsted AG, Thenail C, Luske B, Berg S, Gosme M, Vityi A (2017) How is agroforestry perceived in Europe? An assessment of positive and negative aspects among stakeholders. On-line by Agroforestry Systems.

Gomez JA, Battany M, Renschler CS (2003) Evaluating the impact of soil management on soil loss in olive orchards. Soil Use and Management 19(2): 127-134.

Graves AR, Burgess PJ, Palma JHN, Herzog F, Moreno G, Bertomeu M, Dupraz C, Liagre F, Keesman K, van der Werf W, Koeffeman de Nooy A, van den Briel JP (2007) Development and application of bioeconomic modelling to compare silvoarable, arable and forestry systems in three European countries. Ecological Engineering 29: 434-449.

Graves AR, Burgess PJ, Liagre F, Pisanelli A, Paris P, Moreno G, Bellido M, Mayus M, Postma M, Schindler B, Mantzanas K, Papanastasis VP, Dupraz C (2008) Farmer perceptions of silvoarable systems in seven European countries. Advances in Agroforestry 6: 67-86

Graves AR, Burgess PJ, Liagre F, Dupraz C (2017) Farmer perception of benefits, constraints and opportunities for silvoarable systems: preliminary insights from Bedfordshire, England. Outlook on Agriculture: 46: 1

Isted R (2005) Wood pasture and parkland; overlooked jewels of the English countryside. In: MosquesaLosada MR, McAdam J, Rigueiro-Rodríguez A (eds.) Silvopastoralism and Sustainable Land Management. $\mathrm{CABI}$, Wallingford, UK

Jose S, Gillespie AR, Pallardy SG (2004) Interspecific interactions in temperate agroforestry. Agroforestry Systems 61: 237-255

Lebon G (2016) Observatoire économique cidricole : couts de production $11 \mathrm{P}$. Chambre d'agriculture de Normandie, 6 rue des Roquemonts -14000 Caen France

López-Díaz ML, Moreno G, Bertomeu M (2014) Pasture management under hardwood plantation: legume implantations vs. mineral fertilization. 2nd European Agroforestry Conference. Book of Abstracts. In Palma JHN (eds.). 4 -6/06 Cottbus (Germany), pp 10-13. 
López-Díaz ML, Rolo V, Moreno G (2013) Manejo silvopastoral para la producción de madera de calidad: bases funcionales, productividad y servicios ambientales. 60 Congreso Forestal Español. Monte: Servicios y desarrollo rural. 10-14 junio 2013 Vitoria-Gasteiz. pp. 1-10Mantovani D., Benincasa P., Rosati A. (2016) Olive (Olea europaea L.) and wild asparagus (Asparagus acutifolius L.) agroforestry system: asparagus performance and its best positioning in the olive orchard. In: Book of abstract 3rd European Agroforestry Conference, Montpellier, France, 23-25 May 2016. ISBN: 978-2-87614-717-1, EAN: 9782876147171 . Page: 229-231.

Mantovani D, Rosati A (2014) Does the wild asparagus like olive trees? Spatial and temporal distribution of light in olive orchards and wild asparagus (Asparagus acutifolius) photosynthetic properties. AGROCOOP Conference, Porano, Italy, 16-17 Octobre 2014.

Mantzanas K, Papanastasis V, Pantera A, Papadopoulos A (2015) System Report: Olive Agroforestry in Kassandra, Chalkidiki, Greece. December $2015.28 \%$ pp. http://www.agforward.eu/index.php/en/intercropping-of-olive-groves-in-greece.html

McAdam J, Ward F (2015) System Report: Grazed Orchards in Northern Ireland. November 2015. 12 pp. http://www.agforward.eu/index.php/en/grazed-orchards-in-northern-ireland-uk.html

McAdam J (2014) Initial Stakeholder Meeting Report: Grazed orchards in Northern Ireland, UK. 4 December 2014. 9 pp. Available online: http://www.agforward.eu/index.php/en/grazed-orchards-in-northernireland-uk.html

McAdam JH (2015) Research and Development Protocol for the Grazed Orchards in Northern Ireland. Available at: http://www.agforward.eu/index.php/en/grazed-orchards-in-northern-ireland-uk.html

Métailié JP (2006) La“ dégradation des montagnes" au XIXè siècle dans les Pyrénées. Temps et espaces des crises de l'environnement, 191-210.

Moreno G, López-Díaz ML, Bertomeu García M (2015) System Report: Silvopastoral Management for Quality Wood Production in Spain. September 2015. 16 pp. http://www.agforward.eu/index.php/en/grazing-and-intercropping-of-plantation-trees-inspain.html

Moreno G (2014) Initial Stakeholder Meeting Report Grazing and intercropping of plantation trees in Spain. 17 September 2014. 12 pp. Available online: http://www.agforward.eu/index.php/en/grazing-andintercropping-of-plantation-trees-in-spain.html

Moreno G, Aviron S, Berg S, Crous-Duran J, Franca A, García de Jalón S, Hartel T, Mirck J, Pantera A, Palma JHN, Paulo JA, Re GA, Sanna F, Thenail C, Varga A, Viaud V, Burgess PJ (2017) Agroforestry systems of high nature and cultural value in Europe: provision of commercial goods and other ecosystem services. Submitted to Agroforestry Systems.

Mosquera Losada R, Ferreiro-Domínguez N, Fernández Lorenzo JL, González-Hernández P, Rigueiro Rodríguez A (2014) Initial Stakeholder Meeting Report: Chestnut agroforestry in Galicia, Spain. 23 September 2014. 9 pp. Available online: http://www.agforward.eu/index.php/en/chestnutagroforestry-in-galicia-spain.html

Mosquera Losada R, McAdam JH, Romero-Franco R, Santiago-Freijanes JJ, Rigueiro Rodríguez A (2009) Definitions and components of agroforestry practices in Europe. In Book: Agroforestry in Europe: Current status and future prospects. Springer Science.

Mosquera-Losada R, Santiago Freijanes JJ, Pisanelli A, Rois M, Smith J, den Herder M, Moreno G, Malignier $\mathrm{N}$, Mirazo JR, Lamersdorf N, Ferreiro Dominguez N, Balaguer F, Pantera A, Rigueiro-Rodriguez A, Gonzalez-Hernandez P, Fernandez-Lorenzo JL, Romero-Franco R, Chalmin A, Garcia de Jalon S, Garnett K, Graves A, Burgess PJ (2016) Extent and Success of Current Policy Measures to Promote Agroforestry across Europe. Report, 90p. available online: http://www.agforward.eu/index.php/en/extent-and-success-of-current-policy-measures-topromote-agroforestry-across-europe.html

Nair PKR (1985) Classification of agroforestry systems. Agroforestry Systems 3: 97-128

Pantera A (2014a) Initial Stakeholder Meeting Report: Intercropping of olive groves in Greece (Kassandreia). 20 October $2014 . \quad 8$ pp. Available online: http://www.agforward.eu/index.php/en/intercropping-of-olive-groves-in-greece.html

Pantera A, Burgess P J, Corroyer N, Ferreiro-Domínguez N, Fernández Lorenzo J L, González-Hernández P, Graves A, McAdam J, Moreno G, Mosquera Losada R, Rigueiro Rodríguez A, Rosati A, Upson M (2015) 
Report on Innovations to be examined for Agroforestry for High Value Tree Systems. Available online: http://www.agforward.eu/index.php/en/agroforestry-innovations-to-be-examined-for-high-valuetree-systems.html?file=files/agforward/documents/Milestone3 2 Innovations.pdf

Pantera A, Papadopoulos A, Kasselaki M, Papanastasis V, Mantzanas K, Fotiadis G (2016b) System Report: Agroforestry with Orange Groves in Crete, Greece. January 2016. 9 pp. http://www.agforward.eu/index.php/en/intercropping-of-orange-groves-in-greece.html

Pantera A, Papadopoulos A, Kitsikopoulos D, Mantzanas K, Papanastasis V, Fotiadis G (2016a) System Report: Olive Agroforestry in Molos, Central Greece. January 2016. 9 pp. http://www.agforward.eu/index.php/en/intercropping-of-olive-groves-in-greece.html

Pantera A (2014b) Initial Stakeholder Meeting Report: Intercropping of olive groves in Greece (Molos). 20 October 2014. 9 pp. Available online: http://www.agforward.eu/index.php/en/intercropping-ofolive-groves-in-greece.html

Pantera A (2014c) Initial Stakeholder Meeting Report: Intercropping of Walnut Trees in Greece. 20 October 2014. $8 \mathrm{pp}$. Available online: http://www.agforward.eu/index.php/en/intercropping-of-walnuttrees-in-greece.html

Pantera A (2014d) Initial Stakeholder Meeting Report Intercropping of Orange Groves in Greece. 18 November 2014. 7 pp. Available online: http://www.agforward.eu/index.php/en/intercropping-oforange-groves-in-greece.html

Pantera A, Mouflis G (1996) Agroforestry: combination of forestry, agriculture and/or livestock raising. Proceedings of the A' Panhellenic Conference: Sustainable management of pastures and rangelands", Hellenic Rengelands Society, 46-52.

Papanastasis VP, Mantzanas K, Dini-Papanastasi O, Ispikoudis I (2009) Traditional Agroforestry Systems and Their Evolution in Greece. Agroforestry in Europe. Advances in Agroforestry 6: 89-109.

Pardini A, Mori S, Rigueiro-Rodríguez A, Mosquera-Losada MR (2010) Efecto del arbolado en la producción de pasto y trigo (" Triticum aestivum" L.) ecológicos en la maremma toscana (Italia central). Pastos: 40(2):211-223

Read H (2006) A Brief Review of Pollards and Pollarding in Europe. In 1er Colloque Europeen Sur Led Trognes, 26-28. http://maisonbotanique.fr/dyn/12acte 2 read.pdf.

Robertson H, Marshall D, Slingsby E, Newman G (2012) Economic, biodiversity, resource protection and social values of orchards: a study of six orchards by the Herefordshire Orchards Community Evaluation Project. Natural England Commissioned Reports, Number 090

Rolo V, Moreno G (2012) Interspecific competition induces asymmetrical rooting profile adjustments in shrub encroached open oak woodlands. Trees - Structure and Function, 26: 997-1006.

Rosati A, Mantovani D (2015) System Report: Intercropping of Olive Orchards in Italy. November 2015. 8 pp. $\quad$ http://www.agforward.eu/index.php/en/intercropping-and-grazing-of-olive-orchards-initaly.html

Rosati A (2014) Initial Stakeholder Meeting Report Intercropping and grazing of olive orchards in Italy. 6 August 2014. 7 pp. Available online: http://www.agforward.eu/index.php/en/intercropping-andgrazing-of-olive-orchards-in-italy.html

Rosati A., Caporali S., Paoletti A. (2009) Olive, Asparagus and animals: an agroforestry model for temperate climate in developed countries. Proceedings of the III OLIVEBIOTEQ (For a renovated, profitable and competitive Mediterranean olive growing sector), Sfax, Tunisia, 15-19 December 2009, ISBN: 9789938-9513-0-1, 229-233.

Talbot G, Dupraz C (2012) Simple models for light competition within agroforestry discontinuous tree stands: are leaf clumpiness and light interception by woody parts relevant factors? Agroforestry Systems 84: 101-116.

Tsonkova P, Böhm C, Quinkenstein A, Freese D (2012) Ecological benefits provided by alley cropping systems for production of woody biomass in the temperate region: a review. Agroforestry Systems 85(1): 133152.

Van Lerberghe P, Malignier N (2016) System Report: Traditional Pollard Agroforestry in South-West France. May 2016. 11 pp. http://www.agforward.eu/index.php/en/bordure-trees-in-france-1375.html

Van Lerberghe P, Malignier N (2015) Research and Development Protocol for traditional wood-pasture in France. 17 June 2015. Available on line at: https://www.agforward.eu/index.php/en/bordure-trees- 
in-france-

1375.html?file=files/agforward/documents/WP3 Pollard Branches Biomass protocol.pdf Vossen P (2007) Olive Oil: History, Production, and Characteristics of the World's Classic Oils. HortScience 42(5): 1093-1100. 